\title{
WSUDS (WATER SENSITIVE URBAN DESIGN SYSTEMS) THERMAL BEHAVIOR
}

\section{COMPORTAMIENTO TÉRMICO DE LOS WSUDS (SISTEMAS DE DISEÑO URBANO SENSIBLES AL AGUA)}

\author{
PÉREZ CAMBRA, María del Mar \\ Technical University of Catalonia (UPC) Barcelona School of Architecture \\ Department of Architectural Technology (TA), Centre of Land Policy and Valuations (CPSV) \\ Assistant Professor, Ph.D. Candidate. \\ Av. Diagonal 649, 08028, Barcelona, Spain \\ E-mail: mar.perez@upc.edu \\ Telephone: +34 934012576 \\ ROCA, Josep \\ Technical University of Catalonia (UPC) \\ Department of Architectural Technology (TA), Centre of Land Policy and Valuations (CPSV) \\ Full Professor \\ Av. Diagonal 649, 08028, Barcelona, Spain \\ E-mail: josep.roca@upc.edu \\ Telephone: +34934016396
}

Key words: WSUDs; thermal behavior; water

Palabras clave: WSUDs; comportamiento térmico; agua

\begin{abstract}
The aim of this communication is showing briefly the results of a two-year research about the WSUDs thermal behavior.
\end{abstract}

WSUDs (Water Sensitive Urban Design Systems) try to integrate the urban water cycle in the urban design to improve the environmental behavior in the urbanization of the cities. When we urbanize we transform pervious surfaces into impervious surfaces.

With WSUDs pervious surfaces are implemented. Water presence should improve surfaces thermal behavior. This is the main hypothesis of the research. Thus the question is: are there thermal benefits in using WSUDs that improve outdoor spaces surfaces temperatures?

This question has been tried to be answered with this two year- research. The methodology has been mainly experimental. Some WSUDs Barcelona, built before and during the research, have been thermally measured during some of the warm and cold months of the year with a thermal camera. Some other parameters have also been measured such as environmental temperatures or surface humidity and wind speed. The tools used to do so have been a hygrometer and an anemometer.

During the first years the trend of these surface temperatures showed a "temperance effect" of some WSUDs during the warm months of the year. This "temperance" effect consists in the 
measurement, during the warm months of the year, of some WSUDs surface temperatures to verify they are lower than the environmental temperatures at the same place and moment.

These WSUDs are built with whether green or stone materials. The main difference though between them is the presence of water and how and where it is present in the WSUD. Therefore, depending on how and where water is present in WSUD it causes a strong thermal effect on its surface; stronger than the thermal effect of the material the WSUD is built.

This concept required to be verified; therefore, during the second year of the research a WSUD self-financed was built at the ETSAB experiments yard. There were also some pervious surfaces that helped as well to verify some aspects of the previous year trend registered.

At the end of the article, in the conclusions, the reason is explained. The cause-effect is based in the specific heat of the diatomic molecules due to their thermodynamics behavior. The internal energy of the diatomic molecules is so high that it is hard to increase their temperature. That is the cause of the "temperance effect" that supports this research. This preliminary communication tries to show, analyze and explain this effect, cause of the better thermal behavior of some WSUDs surfaces.

\section{Introduction}

"Water sensitive urban design (WSUD) is an approach to planning and designing urban areas to make use of this valuable resource and reduce the harm it causes to our rivers and creeks." 1 This approach tries to use a better planning, urbanization and construction systems to recuperate water cycle and reuse water. When we urbanize we break water cycle: pervious surfaces become mainly impervious; thus storm water runoff increases after urbanizing much more than before this process and aquifers are hardly recharged.

Storm water runoff also gets to the depuration central station much more polluted after urbanizing if WSUDs are not considered. Therefore, WSUDs approach tries to recuperate water circular cycle life as it's shown in next figure while planning, urbanizing and constructing.

Figure 1. Comparison between WSUDs and traditional planning and design system

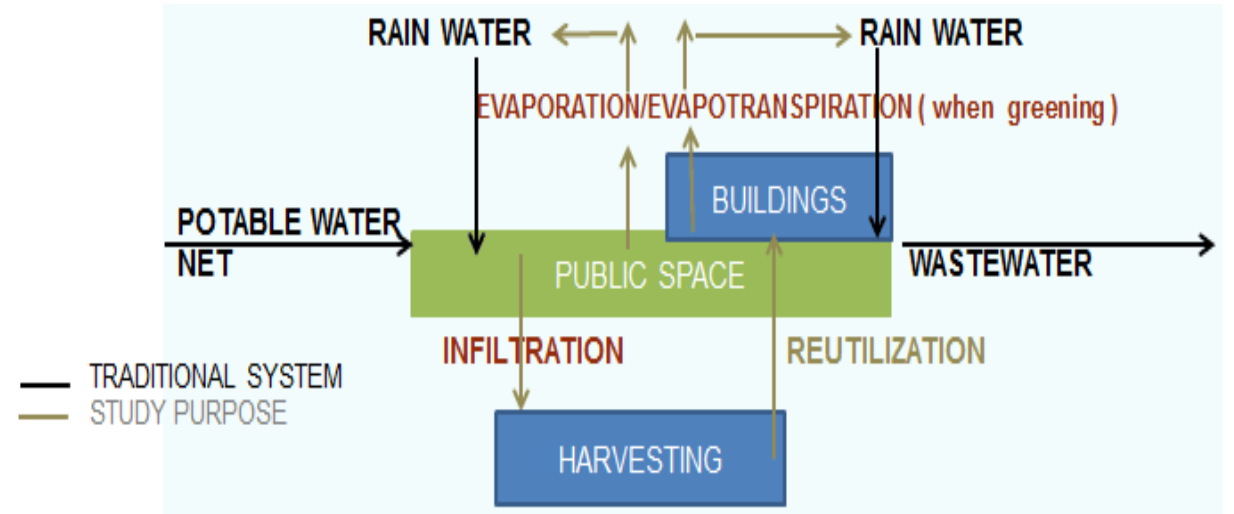

Source: "Sustainable Construction of Public Space". ${ }^{2}$

\footnotetext{
${ }^{1}$ Melbourne Water Corporation.

2 PÉREZ CAMBRA. M. 2013, CTV 2013.
}

Citation: PÉREZ CAMBRA, M. y ROCA, J. WSUDs (Water Sensitive Urban Design Systems) thermal behavior. En: Libro de proceedings, CTV 2018. XII Congreso Internacional Ciudad y Territorio Virtual. "Ciudades y Territorios Inteligentes". UNCuyo, Mendoza, 5-7 septiembre 2018. Barcelona: CPSV, 2018, p. 401-416. 


\section{Objectives}

What happens with temperatures when we urbanize? If we plan the city including pervious surfaces, is it a guarantee to have lower temperatures surfaces during the warm months of the year? Can we really feel a temperate effect on these surfaces due to evapotranspiration or evaporation of the water that could be still retained in those surfaces while descending to the aquifers? This is the departure hypothesis.

\section{Methodology}

The methodology has been mainly experimental. All of them have been thermally measured during some of the warm and cold months of the year with a thermal camera. Due to the rain, permits and management in some of the WSUDs it was impossible to measure everything always in the warmest and coolest months of the year; however, measures have been taken during some of the warm and cold months of the years. There were two days in each situation for each WSUD: $24 \mathrm{~h}$ after raining (what will be called as "wet day") and 24 without raining ("what will be called as dried day"), to see the effect of the water in these construction systems. It allows showing the trend.

As environmental temperatures were not the same in both days, although were similar, a correction has been made as well. Surface temperatures of the wet day have been recalculated if the environmental temperatures of the wet day had been the same as those of the dried day. Some other parameters have also been measured such as environmental temperatures or surface humidity and wind speed. The tools used to do so have been a hygrometer and an anemometer.

\subsection{WSUDs sites}

The first year there were some WSUDs already built which were measured in Barcelona, specifically in Can Cortada and La Fábrica del Sol, in the North and South of the city. During the second year, the verification of the first year results took place at the Architecture School, at the northwest of Barcelona. These sites are shown in the next Figure.

Figure 2. Barcelona City Map showing the WSUDs measured

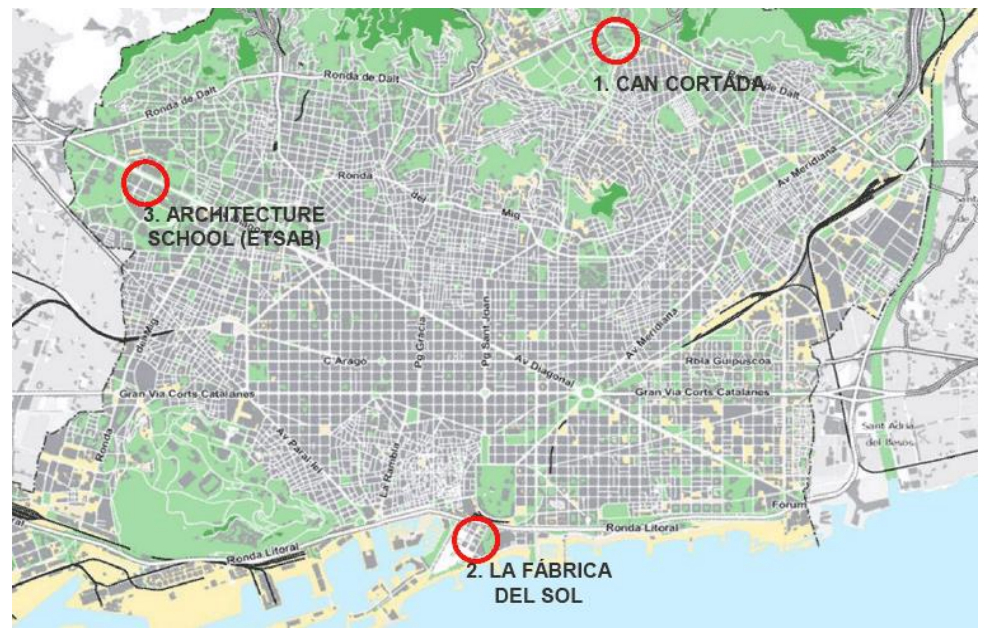

Source: Own elaboration with the Barcelona map

Citation: PÉREZ CAMBRA, M. y ROCA, J. WSUDs (Water Sensitive Urban Design Systems) thermal behavior. En: Libro de proceedings, CTV 2018. XII Congreso Internacional Ciudad y Territorio Virtual. "Ciudades y Territorios Inteligentes". UNCuyo, Mendoza, 5-7 septiembre 2018. Barcelona: CPSV, 2018, p. 401-416. 


\subsection{The WSUDs measured have been}

\subsubsection{1st year in Can Cortada}

a) Can Cortada Detention Basin. "Detention basins are surface storage basins or facilities that provide flow control through attenuation of stormwater runoff. They also facilitate some settling of particulate pollutants. Detention basins arte normally dry and in certain situations the land may also function as recreational facility"3. Gravel (1) and grass (2) where measured (Fig. 3) and draining concrete (3) and polished concrete (4) as well to compare results (Fig. 4).

b)

Figure 3. Can Cortada detention basin.

Figure 5. Can Cortada structural soil tree pit

Figure 4. Can Cortada detention basins and draining concrete pavement
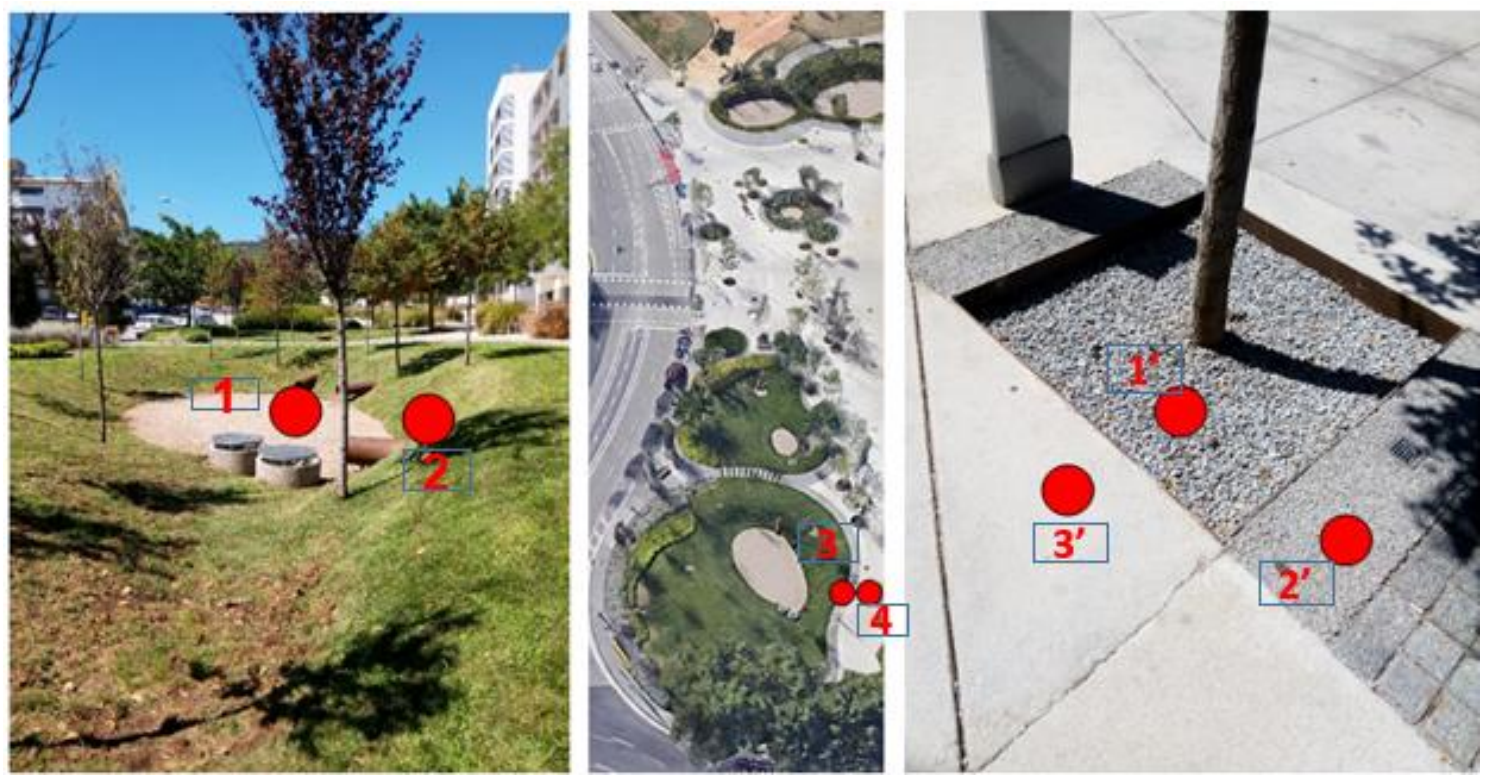

Source: own photographs

c) Draining tree pit with structural soil (1' Fig. 5). "Structural soil with gravel. Composition and application to construction Structural soil is a mixture of gravel and clay soil, to which waterretaining polymers are usually added to facilitate the mixing process and create a more homogenous product". ${ }^{4}$

d) Draining concrete pavement (2' Fig. 5). It's a mixture of Portland cement, gravel, water and additives. Due to the lack of fine aggregates in the mixture the porous structure contains many gaps which allow water and air to circulate within them.

e) Polished concrete in situ pavement (3' Fig.3), It's not a WSUD but was also measured to compare results amongst construction systems. Bagursa was in charge of this urbanization with the architect Roberto Soto. 


\subsubsection{1st year in La Fábrica del Sol}

Figure 6. Blue roof in La Fábrica del Sol

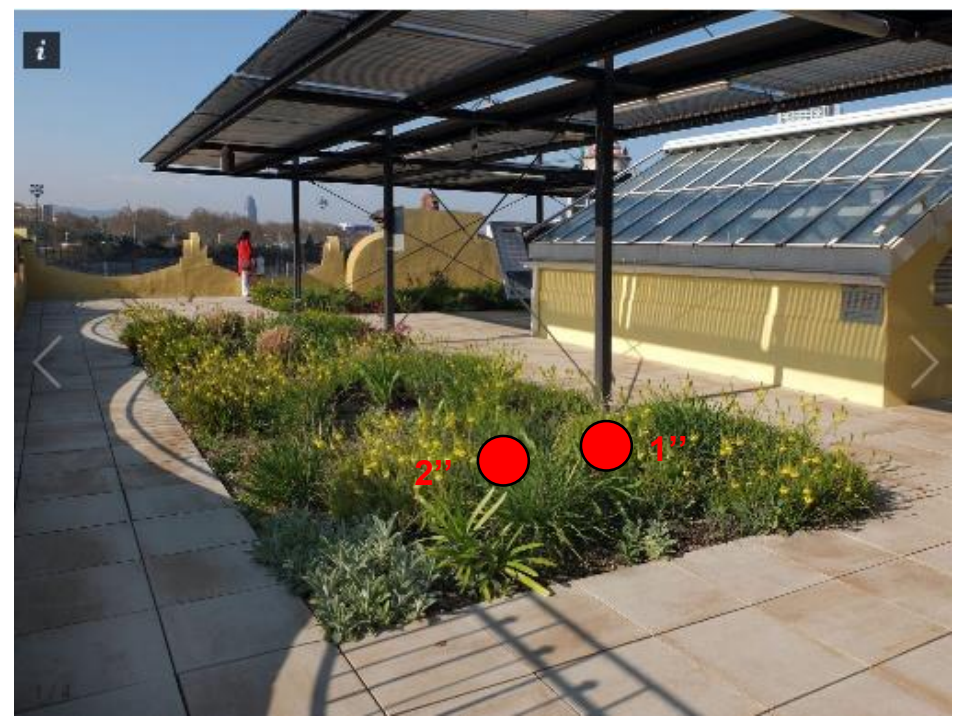

Source: Fabrica del Sol. Ajuntament de Barcelona website

Blue (1") and green and blue roof (2") with $1 \mathrm{~cm}$ open joint and artificial stone pavement: it's a roof that allows the rainwater storage to supply and cover the building hydric requirements. The Architect of this building is Toni Solana.

\subsubsection{2nd year in the Architecture School}

The trend of the WSUDs thermal behavior required verification. The tutor of this research, Dr. Josep Roca asked to the PhD Candidate to check the results somewhere else. The new measurements site chosen was the Architecture School.

There a blue roof $\left(1^{*}\right)$ was built by the author and there was a pervious sloped surface with grass $\left(2^{*}\right)$. In the next chapter we'll see why these draining systems were chosen to be measured.

Figure 8. Blue roof prototype

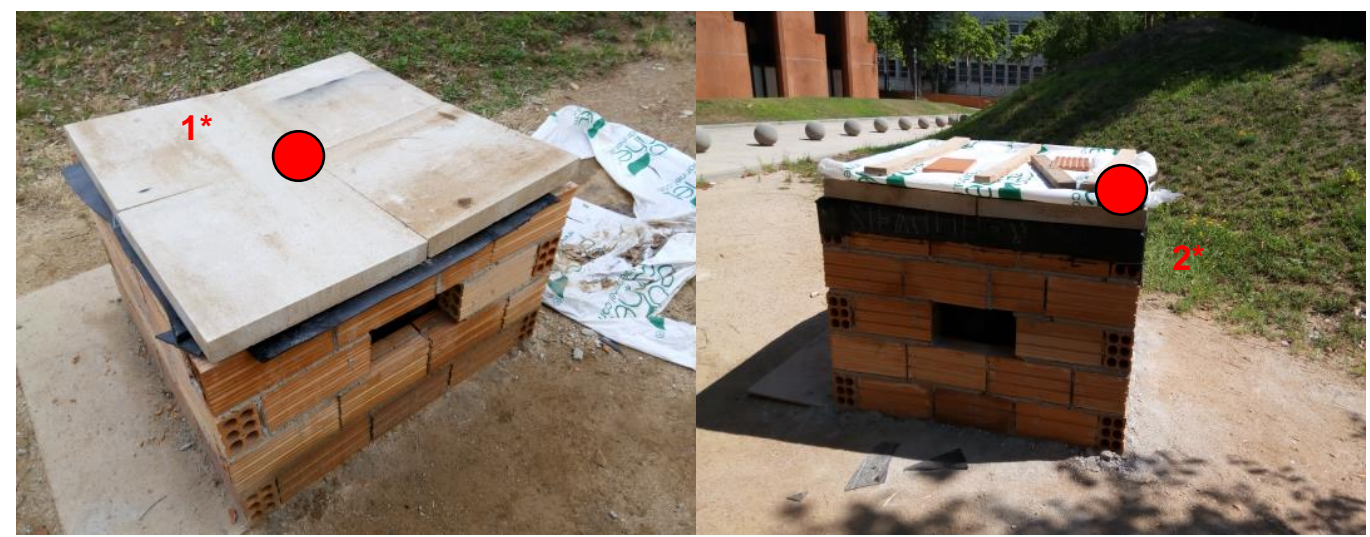

Source: own photography

Citation: PÉREZ CAMBRA, M. y ROCA, J. WSUDs (Water Sensitive Urban Design Systems) thermal behavior. En: Libro de proceedings, CTV 2018. XII Congreso Internacional Ciudad y Territorio Virtual. "Ciudades y Territorios Inteligentes". UNCuyo, Mendoza, 5-7 septiembre 2018. Barcelona: CPSV, 2018, p. 401-416. 


\section{WSUDs data registered and managed}

The goal of the data used is to compare WSUDs surface temperatures in the same points in systems that retain or storage water and systems which does not, in two different days, after raining ("wet day") and after not having rained ("dry day") in warm months of the year and cool months of the year.

The first year will be summarized (although there are statistics) and the second year will be explained showing statistics.

\subsection{1stYear in Can Cortada}

\subsubsection{Can Cortada Detention Basin and sidewalk}

- Surfaces temperatures ranges: amongst the materials measured in this case (draining concrete, gravel, polished concrete and grass) the highest temperatures reached, in the dry day (24/08/2016), by each one in a decreasing order were: (1' Fig. 3 ) gravel $\left(52.7^{\circ} \mathrm{C}\right.$ when environmental temperature was $37.9^{\circ} \mathrm{C}$ ) ( $3^{\prime}$ Fig. 4) draining concrete $\left(49.1^{\circ} \mathrm{C}\right.$ when environmental temperature was $\left.37,2^{\circ} \mathrm{C}\right)$, (4' Fig. 4) polished concrete $\left(41.9^{\circ} \mathrm{C}\right.$ when e. T. was $\left.38.2^{\circ} \mathrm{C}\right)$ and $\left(2^{\prime}\right.$ Fig. 3$)$ grass $\left(34.1^{\circ} \mathrm{C}\right.$ when e. T. was $\left.39.4^{\circ} \mathrm{C}\right)$.

In the wet day (31/08/2016), in a decreasing order, the maximum temperatures were: gravel $\left(47.5^{\circ} \mathrm{C}\right.$ while environmental temperature was $\left.33.5^{\circ} \mathrm{C}\right)$, draining concrete $\left(41.4^{\circ} \mathrm{C}\right.$ while e.T. was $\left.32.8^{\circ} \mathrm{C}\right)$, polished concrete $\left(37.5^{\circ} \mathrm{C}\right.$ while e.T. was $\left.32.5^{\circ} \mathrm{C}\right)$ and grass $\left(31.4^{\circ} \mathrm{C}\right.$ while e.T. was the same).

- The effect of water in this situation tempers the temperature surface in summer. Grass has the lowest temperature surface due to its water retention capacity and evapotranspiration. Gravel is the worst in this case because is the purest stoned material (with a high thermal inertia) and it can't retain water. It also filters it to the subsoil. The only surface measured which is not a WSUDs, polished concrete, retains water in its surface and it reaches lower temperatures than draining concrete which just let rainwater runoff descend through the air cavities it contains right to the subsoil.

- Surface temperatures and environmental temperatures differences are in all cases lower the day after raining than the ones measured the day after not having rained the previous day. The only case which surface temperatures are lower than environmental temperatures, in summer, during the whole day, is grass.

- Environmental temperatures during the "dry day" and the "wet day" measured are not the same and comparing surface temperatures between them depend on several parameters, a correction was made supposing that environmental temperatures were the same in both days to see just a trend (and not an exact result) of how the wet day surface temperature would have been in the dray day. In all cases the result was that surface temperatures would have been lower in the wet day if environmental temperatures had been the same in summer. 
Temperatures were taken in the same way and places in February. The result in the cold months of the year is not that critical in Barcelona because there are not extreme temperatures. In summer it's more critical because of the excessive heat. Briefly, in February, surface temperatures reached were in general higher in the dry day.

Water didn't decrease especially the surface temperatures but if we had made the little correction explained before just to see what would have happened with the wet day surface temperatures if environmental temperature had been the same as the dry day ones, surface temperatures in the wet day would have been in all cases lower than surface temperatures in the dry day again.

1'. Draining tree pit with structural soil: during the dry day (24/08/2016) the highest temperature reached was $48.5^{\circ} \mathrm{C}$ (while environmental temperature was $36.5^{\circ} \mathrm{C}$ ). During the wet day $(31 / 08 / 2016)$ the highest temperature was $46.2^{\circ} \mathrm{C}$ (while e.T. was $38.1^{\circ} \mathrm{C}$ ). However, when the little correction just to see the trend is calculated surface temperatures in the wet day are more or less the same than they would have been in the dry day if environmental temperatures would have been the same because water is hardly retained in this system. The, there is no water thermal effect.

2'. Draining concrete pavement (Figure 3). It happens more or less the same in draining concrete; it has a similar pattern behavior as structural soil. The difference though is that surface temperatures are a bit lower than with structural soil, probably due to its draining capacity. The highest temperature during the dry day it was $45.3^{\circ} \mathrm{C}$ (while e.T. was $36^{\circ} \mathrm{C}$ ) and during the wet day it was $42.6^{\circ} \mathrm{C}$ (while e.T. was $37.9^{\circ} \mathrm{C}$ ).

3'. Polished concrete: curiously its behavior is a bit different from the other two because the day after raining surface temperatures are lower than environmental temperatures on date $24 / 08 / 2016$. During the dry day $(31 / 08 / 2016)$ surface temperatures are higher than environmental only during one hour (from 16:00h to 17:00h) while in the other two cases it happens until 20h. It must have more thermal inertia because it reaches lower temperatures than the other two materials: $35.5^{\circ} \mathrm{C}$ (while e.T. was $35.1^{\circ} \mathrm{C}$ ) during the dry day and $33,4^{\circ} \mathrm{C}$ (while e.T. was $30.2^{\circ} \mathrm{C}$ ) during the dry day. After equaling environmental temperatures to see what happened the wet day surface temperatures were slightly lower than the dry day surface temperatures.

In the three cases, during the dry day (21/02/17) and the wet day (15/02/17) surfaces temperatures were lower than environmental temperatures (but it's not a benefit)

\subsection{1stYear in La Fábrica del Sol}

1". Blue (1") roof with $1 \mathrm{~cm}$ open joint and artificial stone pavement thermal behavior:

This construction system has the best thermal behavior analyzed during the first year. During the dry day (12/09/2016) the highest surface temperature was $27.5^{\circ} \mathrm{C}$ (while environmental temperature was $\left.29.5^{\circ} \mathrm{C}\right)$. During the wet day (14/09/2016) the highest surface temperature was $18.6^{\circ} \mathrm{C}$ (while e.T. was $33.2^{\circ} \mathrm{C}$ ). If environmental temperatures were equaled the surface temperatures of the wet day would be an average of $3^{\circ} \mathrm{C}$ lower than the surface temperatures in the dry day.

Citation: PÉREZ CAMBRA, M. y ROCA, J. WSUDs (Water Sensitive Urban Design Systems) thermal behavior. En: Libro de proceedings, CTV 2018. XII Congreso Internacional Ciudad y Territorio Virtual. "Ciudades y Territorios Inteligentes". UNCuyo, Mendoza, 5-7 septiembre 2018. Barcelona: CPSV, 2018, p. 401-416. 
2". Green and blue roof (2") with $1 \mathrm{~cm}$ open joint and artificial stone pavement:

The same solution of the blue roof with shrubby vegetation on the artificial stone shows, during the dry day, a $27.3^{\circ} \mathrm{C}$ surface temperature (as the highest one, while the e.T. is $34.3^{\circ} \mathrm{C}$ ). The highest temperature during the wet day is $19.5^{\circ} \mathrm{C}$ (while the e.T. is $19.5^{\circ} \mathrm{C}$ ). If we equal environmental temperatures the surface temperatures during the wet day are lower than the ones during the dry day but there is not an average with vegetation.

In February, during the wet day both solutions have lower surface temperatures than the environmental temperatures. However, during the dry day surface temperatures go above environmental temperatures about 14:00h., after having received the sun heat during the previous hours. In the green-blue-roof case there are some pics which are above the environmental temperature.

\subsection{Conclusions during the first year}

Brief, during the first year: from August-September 2016 until February 2017 the only construction systems than showed a lower surface temperature than the environmental temperature during the hot months of the year were the grass sloped surface of the Detention Basin in Can Cortada and the Blue and the Green-Blue roof of La Fábrica del Sol.

In both cases, the common factor which is the presence of water: retained in the grass of the Detention Basin and existing water surface underneath the artificial stone. The presence of water also decreased other surfaces which are not WSUDs such as polished concrete because it's retained in its surface. That's why it was also lower than the environmental temperature during the wet day in summer.

In winter results are not that critical because there are not extreme temperatures but the results have also been explained in this article.

As water presence modified the surface temperatures Dr. Josep Roca asked the Phd candidate Mar Pérez to build a blue roof similar to the one of la Fábrica del Sol in the construction experiments yard of the Architecture School to verify results.

This prototype could be built in September of 2017 (permits delayed its construction). As there was a grass slope close to the prototype it was also measured to check also the thermal behavior.

\subsection{2nd Year in the Architecture School}

The prototype was built in September 2017. It was $1 \times 1 \times 1 \mathrm{~m}$. It was a similar blue roof to the La Fábrica del Sol one except for the structure, to verify the effect of water in the surface temperature: Isolation layer is underneath impervious membrane like in walkable conventional roofs, there were also an air chamber and an identical artificial stone with a draining open joint.

Citation: PÉREZ CAMBRA, M. y ROCA, J. WSUDs (Water Sensitive Urban Design Systems) thermal behavior. En: Libro de proceedings, CTV 2018. XII Congreso Internacional Ciudad y Territorio Virtual. "Ciudades y Territorios Inteligentes". UNCuyo, Mendoza, 5-7 septiembre 2018. Barcelona: CPSV, 2018, p. 401-416. 
Figure 9. Blue roof prototype

Figure10. La Fábrica del Sol Blue roof
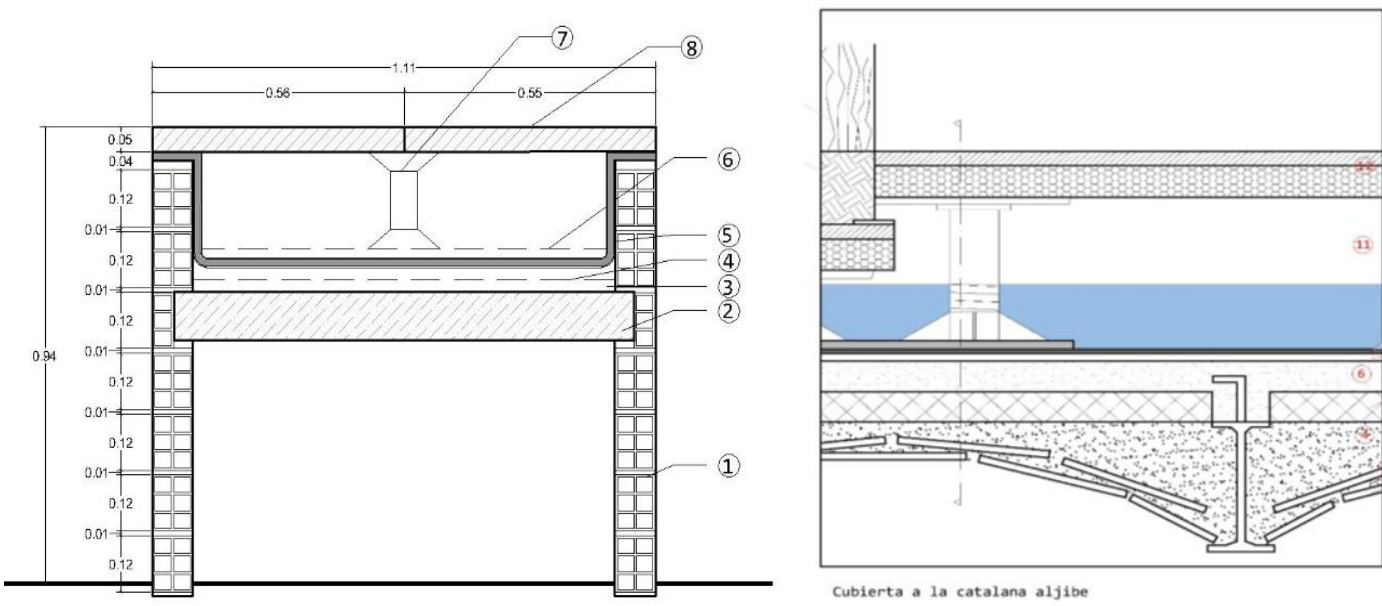

Cubierta a la catalana aljibe

1. Brick wall: $24 \times 1,5 \times 9 \mathrm{~cm}$.

1. Quarry tile $2 \mathrm{~cm}$.

Wood conglomerate resins support $10 \mathrm{~m}$.

3. Thermal Isolation $5 \mathrm{~cm}$. (According to the norm).

4. Geotextile $2 \mathrm{~mm}$.

5. Impervious membrane $2 \mathrm{~mm}$.

6. Anti-prick geotextile $2 \mathrm{~mm}$.

7. Self-regulating pylon.

8. Artificial stone, $5 \times 50 \mathrm{~cm} \times 50 \mathrm{~cm}$.

2. Portland cement mortar $2 \mathrm{~cm}$.

3. Quarry tile $2 \mathrm{~cm}$.

4. Plain concrete $2 \mathrm{~cm}$ minimum

5. Thermal Isolation $7 \mathrm{~cm}$.

6. Reinforced concrete $5 \mathrm{~cm}$.

7. Perlite leveling layer $3 \mathrm{~cm}$.

8. Impervious membrane $2 \mathrm{~mm}$. Ventilated air chamber is $30 \mathrm{~cm}$.

9. Anti-prick geotextile $2 \mathrm{~mm}$.

10. Water.

11. Ventilated air chamber is $30 \mathrm{~cm}$. Without water.

12. Artificial stone $5 \times 50 \mathrm{~cm} \times 50 \mathrm{~cm}$. Supported by a self-regulating pylon

Source: own elaboration

Measurements start immediately after the Blue Roof prototype construction, 20/09/2017, a dry day. During dry day the blue roof had no water in the ventilated chamber of the prototype. Thus, surface temperatures were above the environmental temperatures in the hottest temperatures of the day (from 11:30-17:30h). That day, environmental surface of the grass was always lower than environmental temperatures but close to them $\left(1^{\circ}-1.9^{\circ} \mathrm{C}\right)$ during the hottest hours of the day (from 11:00 to 13:00h).

Graphic 1 . Artificial stone with $1 \mathrm{~cm}$ draining open joint: surface to $20 / 09 / 2017$ Dry day

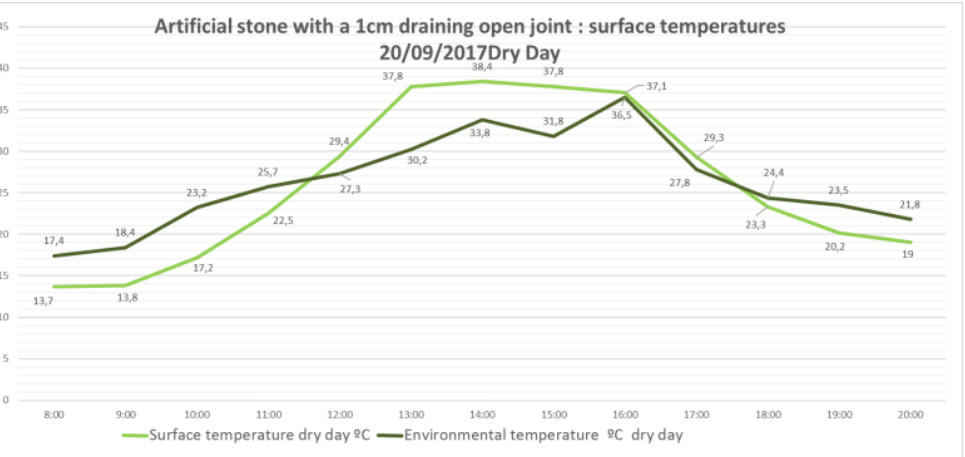

Source: own elaboration

Citation: PÉREZ CAMBRA, M. y ROCA, J. WSUDs (Water Sensitive Urban Design Systems) thermal behavior. En: Libro de proceedings, CTV 2018. XII Congreso Internacional Ciudad y Territorio Virtual. "Ciudades y Territorios Inteligentes". UNCuyo, Mendoza, 5-7 septiembre 2018. Barcelona: CPSV, 2018, p. 401-416. 
However, the day after raining, when water was present in the prototype ventilated chamber $\left(6 \mathrm{~cm}\right.$.), temperature of the stone decreased below environmental temperature between $5.9^{\circ} \mathrm{C}$ and $1.1^{\circ} \mathrm{C}$.

\section{Graphic 2. Artificial stone with $1 \mathrm{~cm}$ draining open joint: surface to $20 / 10 / 2018$ Wet day}

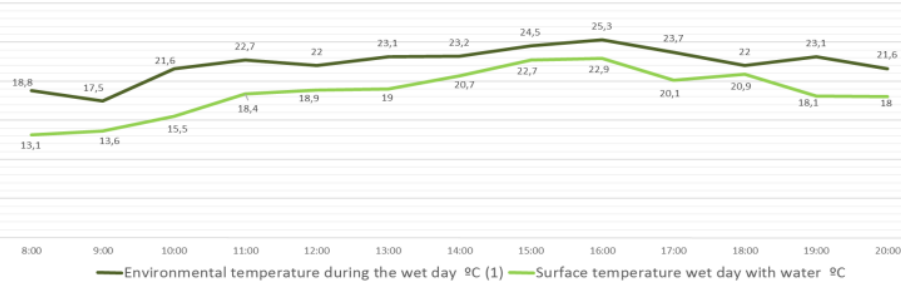

Source: own elaboration

The only difference between both situations is the presence of water. It happened something similar with grass. Grass surface temperature is below the environmental temperature that day because evapotranspiration also contributes to it but surface temperature almost reach the environmental one it during the warmest hours of the day (from 11-13h).

\section{Graphic 3. Graas surface to $20 / 09 / 2017$ Dry day}

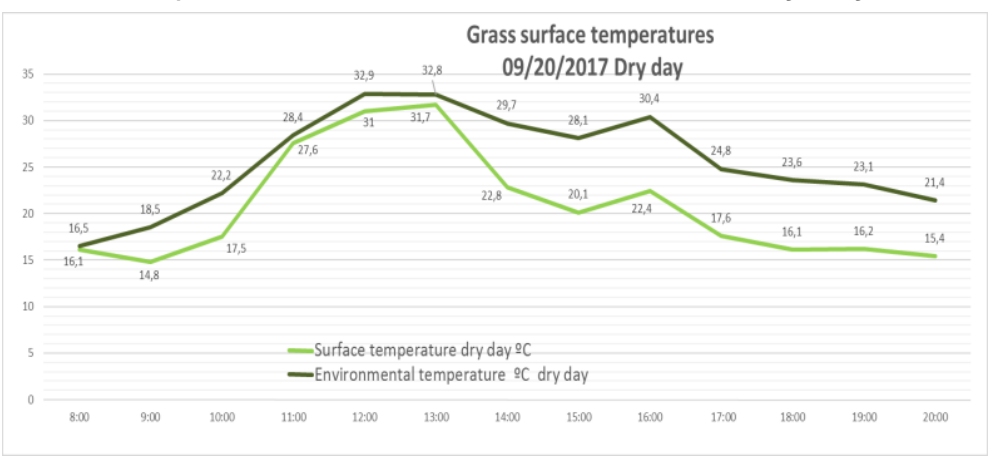

Source: own elaboration

After raining, differences between bot temperatures are higher as it's shown in the next statistic with the water retained in the vegetation (and the evapotranspiration).

Graphic 4. Graas surface to $20 / 09 / 2017$ Wet day

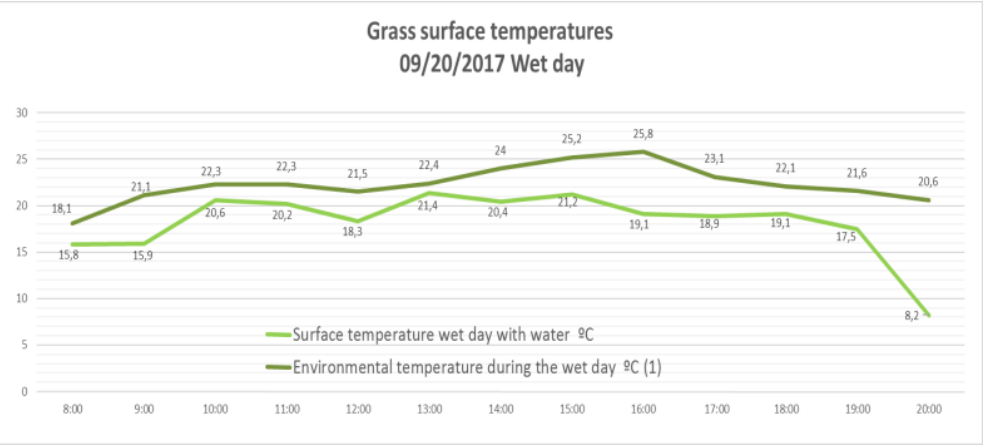

Source: own elaboration

Citation: PÉREZ CAMBRA, M. y ROCA, J. WSUDs (Water Sensitive Urban Design Systems) thermal behavior. En: Libro de proceedings, CTV 2018. XII Congreso Internacional Ciudad y Territorio Virtual. "Ciudades y Territorios Inteligentes". UNCuyo, Mendoza, 5-7 septiembre 2018. Barcelona: CPSV, 2018, p. 401-416. 
Environmental temperatures were not the same during both days. Although surface temperatures can't be calculated numerically as if the wet day had the same environmental temperature as the wet day, this little mathematical approximation was done just to see wat happened.

\section{Graphic 5. Artificial stone with 1cm draining... Comparative 20/09/2017 - 20/10/2018}

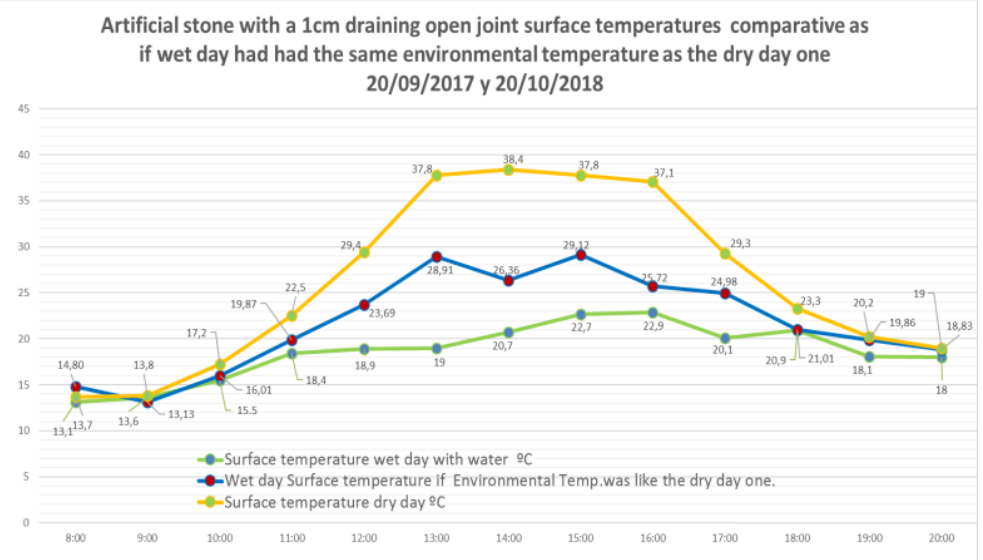

Source: own elaboration

If the environmental temperature had been the same during the wet day as during the dry day, surfaces temperatures of the wet day (blue color) would have been lower than those of the dry day (yellow color). This little, but not precise, correction shows the trend that they would have been lower. It happens the same with the sloped grass surface:

\section{Graphic 6. Graas surface to… 20/09/2017 and 20/10/2018}

Grass surface temperatures comparative as if wet day had had the same environmental temperature as the dry day one

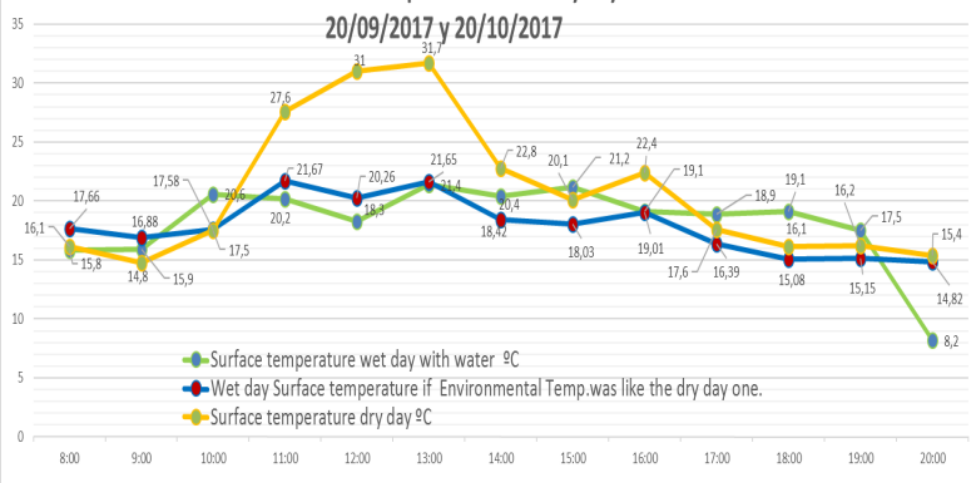

Source: own elaboration

As Dr. Roca asked the PhD candidate Mar Pérez to verify these results removing the ventilated air chamber to see if it was just because of the water presence during the warm months of the year, the ventilated chamber was substituted by $5 \mathrm{~cm}$. of sand and the joint was closed $(0 \mathrm{~cm})$ in the prototype.

Citation: PÉREZ CAMBRA, M. y ROCA, J. WSUDs (Water Sensitive Urban Design Systems) thermal behavior. En: Libro de proceedings, CTV 2018. XII Congreso Internacional Ciudad y Territorio Virtual. "Ciudades y Territorios Inteligentes". UNCuyo, Mendoza, 5-7 septiembre 2018. Barcelona: CPSV, 2018, p. 401-416. 
Thus, there won't be any water surface underneath. We'll see that during the dry and wet days surface temperatures were above environmental temperatures from 11:00 $\mathrm{h}$ till the end of the day.

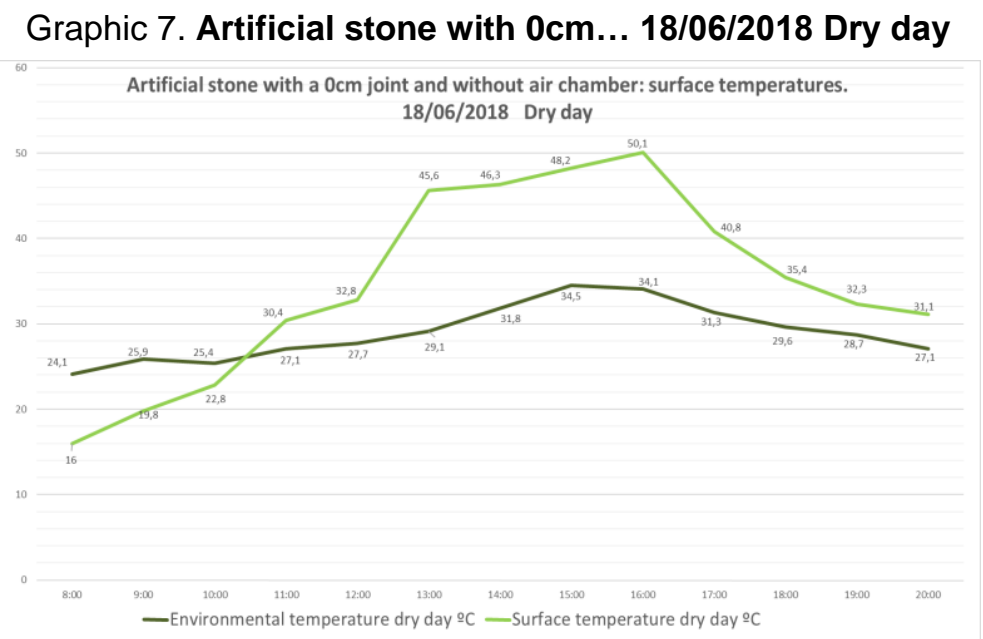

Source: own elaboration

Graphic 8. Artificial stone with 0cm... 31/05/2018 Wet day

Artificial stone with a $0 \mathrm{~cm}$ joint and without air chamber: surface temperatures. 31/05/2018 Wet day

Source: own elaboration

The sloped grass surface next to it was also measured. Grass usually has the surface temperature under the environmental temperatures during the whole year; however, sometimes there are occasional picks of surface temperature which are above the environmental temperatures.

Trying to understand why it happens Relative Humidity ("HR") measured in \% and wind speed is also shown in the next statistics.

These picks usually coincide when there are fast descend of the Grass Relative Humidity as it produced a "fast dry" of the grass and a sudden increase of its surface temperature. 


\section{Graphic 9. Graas surface to $\mathbf{1 8} / 06 / 2018$ Dry day}

Grass: surface temperatures. 18/06/2018 Dry

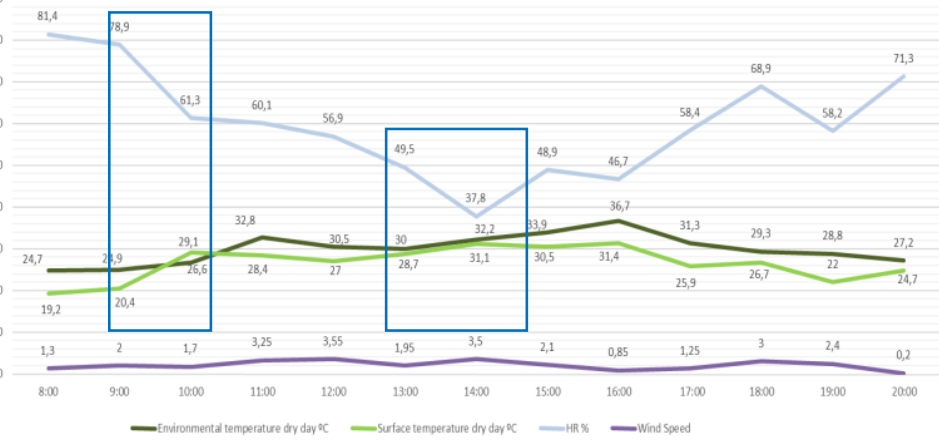

Source: own elaboration

\section{Graphic 9. Graas surface to $31 / 05 / 2018$ Wet day}

Grass: surface temperatures

$31 / 05 / 2018$ Wet day

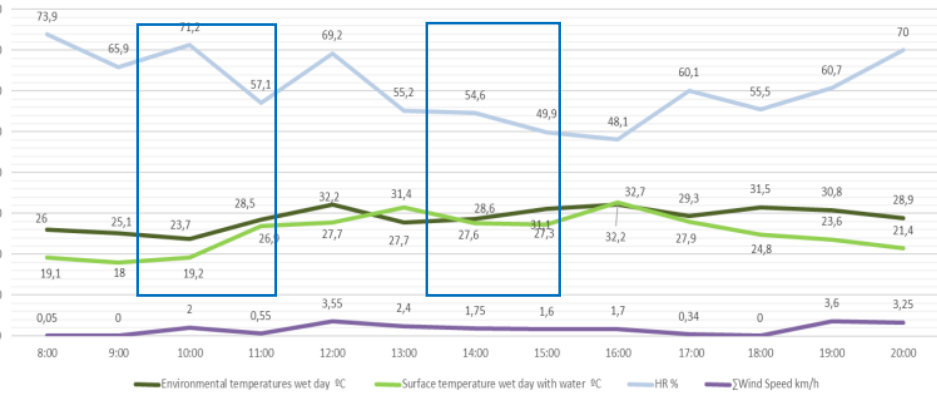

Source: own elaboration

If we made the correction explained before just to see the surface temperatures equaling numerically environmental temperatures the result would be unsatisfactory with the conventional roof (it's not a blue roof anymore). The result is irregular.

Graphic 9. Artificial stone with $0 \mathrm{~cm} \ldots$... Comparative 18/06/2018 - 31/05/2018

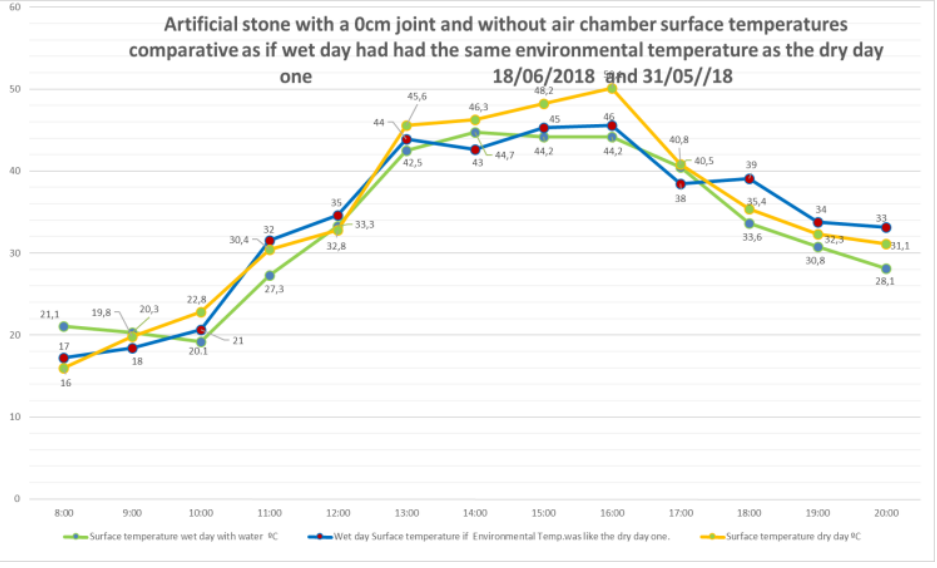

Source: own elaboration

Citation: PÉREZ CAMBRA, M. y ROCA, J. WSUDs (Water Sensitive Urban Design Systems) thermal behavior. En: Libro de proceedings, CTV 2018. XII Congreso Internacional Ciudad y Territorio Virtual. "Ciudades y Territorios Inteligentes". UNCuyo, Mendoza, 5-7 septiembre 2018. Barcelona: CPSV, 2018, p. 401-416. 


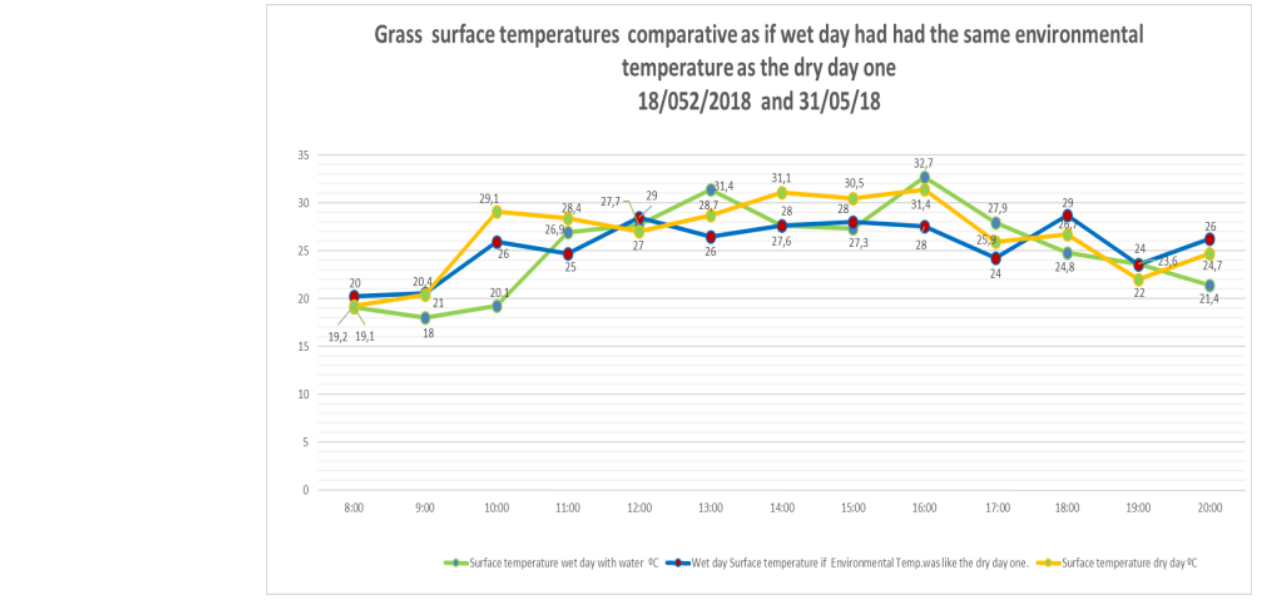

Source: own elaboration

The grass statistic shows in general a better surface temperatures behavior of the wet compared to the dry day except for the 12:00 h., pick and a later pick about 18:00 h., instead of the $16: 00 \mathrm{~h}$.

\section{Conclusions}

In general, during these two years WSUDs which could contain more water showed better surface temperature behaviors in Barcelona during the warm months of the year. These were: systems with vegetation (as the sloped grass surface) and the blue roof when it contained water.

The reason why water in direct or indirect contact with these surfaces is because its high specific heat. Monoatomic gases have only translational movements, three freedom ranges: $x$, $y, z$.

However, molecules with more atoms like water have two more movements: vibrational and internal movements which endow these molecules with a high energy grade called specific heat.

This specific heat is the quantity of energy required to increase one molecule $1^{\circ} \mathrm{C}$ of temperature. In the case of water it's $4.12 \mathrm{Jxmol}-1 \mathrm{xK}-1$. Thus, in the case of water, it's very hard to increase its temperature.

That's why it's harder to increase surface temperatures in contact (direct or indirect) with water although environmental temperatures are higher. Then, WSUDs in contact with water have a better behavior than WSUDs with a faster drain system.

If this surface temperature can affect to thermal comfort and how, in the city canyons of the urban area, under the geostrophic wind it's a next step. 
Figure 11. Heat Island behavior in the Urban Areas

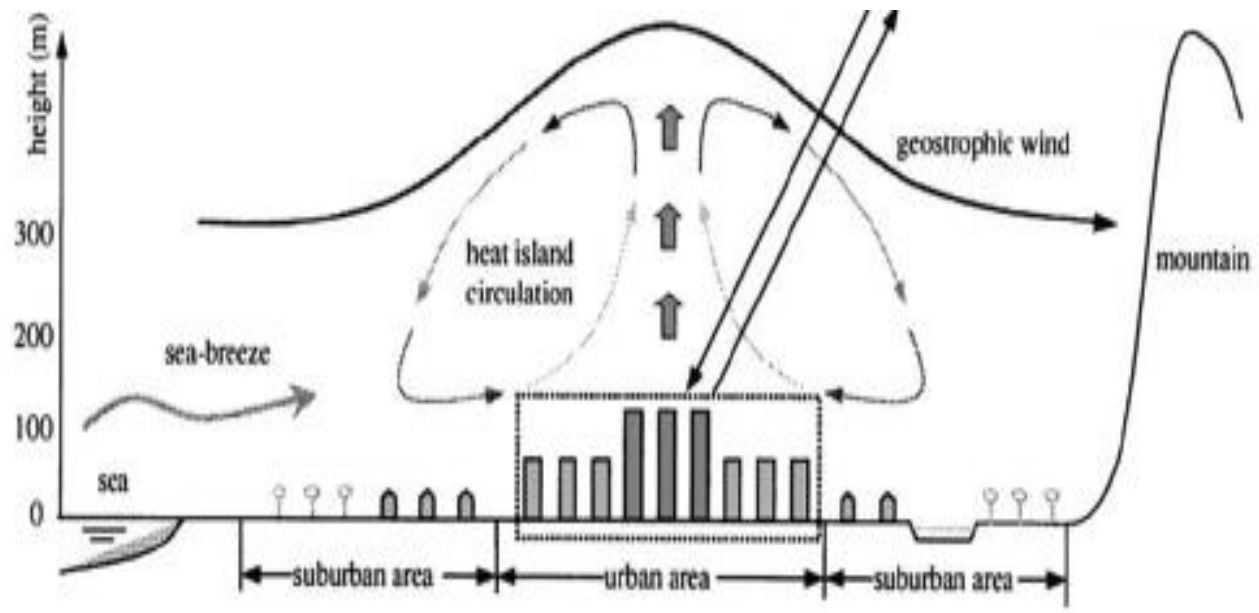

(4) Uitan scale $(10 \mathrm{~km} \sim 100 \mathrm{~km})$

Source: Water Sensitives Cities: Impacts of water sensitive urban design solutions on human thermal comfort ${ }^{5}$

\section{Acknowledgments}

Special thanks to Dr. Josep Roca Cladera, Dr. Fausto G. Hedgart, Dr. Maria Dolors Martinez Santafé and Dr. Qian Liyuan, for their patience during this research.

And also thanks to the architects team who have contributed in this research, helping with the registers during these two years and the data management which has been briefly exposed in this article: Architects and M,Sc Landscapers (ETSAB-UPC): Nayharis Batista, Ruth Fernández Farreras, Joeli Camacho, Curro Peña and Sandra Desirée Pagan; Mireia Torres, Architect (ETSAB-UPC) and Marga Santaeulària Solans (ETSAB-UPC); Architect, Marketing and International Sales Postgraduate Degree and Transversal Occupation Projects Manager and their Events Organizer in Barcelona Activa.

\section{Bibliography}

BESTARD, A. AB Paisatgistes. Suelo estructural. En: Paisajismo Landscape Architecture, PAISEA, 21. Barcelona, Junio 2012. p. 104-111. ISSN 1887-2557. Disponible en: http://abpaisatgistes.cat/sites/default/files/pdf 121.pdf

CIRIA. PUB C697 SUDS manual. 2007. p. 347. [En línea] Disponible en: https://www.thenbs.com/PublicationIndex/documents/details?Pub=CIRIA\&DocID=281766

COUTTS, A.; LOUGHNAN, M.; TAPPER, N.; WHITE, E.; THOM, J.; BROADBENT, A. \& HARRIS, R. The impacts of WSUD solutions on human thermal comfort: Green Cities and Micro-climate. Cooperative Research Centre for Water Sensitive Cities, Monash University, December 2014. 
FABRICA DEL SOL. Ajuntament de Barcelona. [En línea] Disponible en http://ajuntament.barcelona.cat/lafabricadelsol/es

MELBOURNE WATER CORPORATION [En línea] Disponible en: https://www.melbournewater.com.au

PÉREZ CAMBRA, M. Sustainable Construction of Public Space. En: International Conference Virtual City and Territory. "9॰ Congresso Città e Territorio Virtuale, Roma, 2, 3 y 4 de Octubre 2013. Roma: Università degli Studi Roma Tre, 2014, p. 575-587. [En línea] Disponible en: http://hdl.handle.net/2099/16219 